\section{EMBRYRIDDLE}

Aeronautical University

SCHOLARLY COMMONS
Journal of Aviation/Aerospace Education \& Research

Volume 9

Number 2 JAAER Winter 2000

Article 8

Winter 2000

\title{
Pilot Education: The Beginnings
}

Tim Brady

bradyt@erau.edu

Follow this and additional works at: https://commons.erau.edu/jaaer

\section{Scholarly Commons Citation}

Brady, T. (2000). Pilot Education: The Beginnings. Journal of Aviation/Aerospace Education \& Research, 9(2). https://doi.org/10.15394/jaaer.2000.1251

This Article is brought to you for free and open access by the Journals at Scholarly Commons. It has been accepted for inclusion in Journal of Aviation/Aerospace Education \& Research by an authorized administrator of Scholarly Commons. For more information, please contact commons@erau.edu. 


\title{
PILOT EDUCATION: THE BEGINNINGS
}

\author{
Tim Brady
}
The engine is the heart of an airplane, but the pilot is its soul.
Walter Raleigh (in Saunders, 1945)

For those of us involved with flight education, it is easy to take for granted some of the concepts that we practice daily, concepts such as a standardized flight curriculum, periodic flight checks, clearly defined flight instruction procedures, and progression from the simple to the more complex aircraft. These concepts did not simply appear full-blown, they were born, shaped, and modified via the crucible of world conflict. To find the roots of these flight education concepts, we have to look to Europe, to the early days of flight, to 1914, to what we now call World War I.

At the beginning of the Great War, as it was then called, flight training was similar in most European countries on both sides of the conflict. Overall there was little or no organized curriculum and there was a hodgepodge of training aircraft. In some aircraft, the student sat above and behind the instructor. The instructor's cockpit had no stick, no wheel, and no pedals. The instructor could communicate only by leaning over the side of the cockpit, cutting the engine, and shouting at the student.

There were as many training methodologies as there were instructors, and no thought had been given to training military pilots to do other than fly the aircraft for the purpose of reconnaissance. Students often soloed with only one and a half hours of flying time.

Let us now look at the various methods of flight training that were used in Europe and how they impacted the development of pilot training here in the U.S.

\section{The English Method}

Prior to the beginning of the war, a military student pilot received instruction on how to fly at the Central Flying School (CFS) of the Royal Flying Corps (RFC). However, little mention was made of military subjects such as aerial photography, bomb-dropping or the use of the Awireless.@ Students began their training in Farmans, a flimsy aircraft at best, with a period of dual instruction. After soloing the aircraft and flying a few cross countries, the student then moved to a more advanced aircraft such as the AVRO or BE-
2 in which they received dual instruction and then flew solo for a few flights. Their final test was a cross-country flight at about 3,000 feet followed by a dead-stick spiral approach and landing.

At the beginning of the war, England sent most of her aviation resources to the front except those at the Central Flying School. It was mostly stripped of both airplanes and instructors to bolster the units at the front. This decision began to take its toll as the number of pilots produced did not meet the levels of attrition. To resolve this problem, England set up many reserve squadrons based in England that would provide initial training in the Farman aircraft. Then the student would move either to the CFS or to a service squadron to receive advanced training. After some experimentation, the system that evolved was one which the casualties were replaced out of resources produced at the CFS. The reserve squadrons acted as units where complete squadrons could be built up, trained then broken off as complete units and sent to the front. Further training would take place in the mission aircraft at the front. This system served their needs at first, but as experience with the military uses of aircraft grew so did the need for advanced training. Eventually, more training was needed in such areas as maneuvers, formation flying, and other flight skills unique to combat.

Next a three-phase system was put into place using the reserve squadron and CFS structure. The student first received training in a primary aircraft in which basic, elementary flying 
skills were taught. The next phase was in an advanced squadron where an advanced aircraft was used and the student was taught more flight maneuvers. More knowledge about the military uses of the airplane and its systems were discussed in this phase. From there, students moved to the third tier, the operational squadron, where they learned combat procedures and tactics, many times while in combat.

This system worked reasonably well, but had some serious shortcomings such as (Brown, 1980, pp. 45-47):

1) there was no standardized method of conducting the training at any level; the instructor was on his own his own and taught what he felt was necessary by means of the method that he thought was appropriate to the subject,

2) there was no system to the instruction and

3) communication between the instructor and student was woefully inadequate, consisting mostly of shouting above the wind and engine noise. Clearly, something had to be done. The Gosport System. The Royal Flying Corps set up an experimental group near the village of Gosport, England to study and improve pilot training. The outcome of this study was a system that had two defining characteristics: standardized training and effective communication.

Standardized Training. The three-stage system was retained, but in the first two stages were taught at schools in England under a standardized flight training curriculum. In each of the first two phases, a student was assigned to an instructor with whom he remained for the duration of the training in that stage. Flight checks were given by other instructors. The flight checks by other instructors were done not only to assess the proficiency of the student, but also to insure that the standards were being met by their instructors. The goals of the first two stages of training were to teach the students how to fly and also to teach them procedures and tactics common to all of the combat aircraft they would eventually fly.

In the third stage, the training was conducted in the operational unit and by different instructors. Here it was felt that the more exposure to the various techniques of combat veterans in a rapidly changing environment, the better the quality of the training.

Communication. The Gosport system also introduced an excellent form of one-way communication. Two cups were sewn into the students helmets, one over each ear. Hollow rubber tubes were inserted into the cups, joined as one tube and snaked between the cockpits. At the other end of the device, the tube was connected to a funnel device into which the instructor spoke. The student could hear the instructor perfectly, however, they could not respond (Brown, 1980).

The Gosport system was very effective in reaching its goals. In 1917, Brigadier-General W.S. Brachner (1917, pp. 242243), who was the RFC officer in charge of flight training for the RFC during most of the war, describes the training this way:

The student) first has to join the service as a cadet and go through a course in the Cadet's School, at which military subjects, pure and simple, are taught. He gets a grounding of drill and discipline, care of arms, interior of economy, military law and the use of the machine gun; this course lasts about two months. From this the Cadet is sent to a Flying Corps training school, where he begins his technical training on the ground. He goes through a course in the care of engines and rigging. He is given some ideas on the theory of flight. He is taught wireless signaling and receiving. He gets instruction in the care of machine guns, in the use of the camera, in map reading, in the observation of artillery fire with models, and in his spare moments he gets a certain amount of drill. This course lasts another two months, and if he gets through this successfully, he is given a commission ... He then joins a preliminary training squadron as a pupil, and starts his instruction usually on a Maurice Farman, his training on military and technical subjects going on concurrently. After reaching a certain standard of efficiency and having completed a certain number of hours in the air, he is sent on to an advanced training squadron or service squadron, where he learns to fly service types of machines for military purposes and eventually qualifies for his wings. He is then gazetted as a Flying Officer of the R.F.C. and posted to a service squadron . . . During the period of advanced training he goes through a course of aerial gunnery... The total time in the air usually required to reach the qualification stage is about thirty hours solo ... flying up to a certain standard is

extraordinarily easy, but the standard of military qualifications is getting higher and higher, and more difficult to attain, and at the same time the quality of our flying demanded is growing greater every day.

\section{The French System}

The French used a similar system to that of the British to 
train their bomber and reconnaissance pilots. However, for their chasse pilots (in today's vernacular, fighter pilots), it was an entirely different story.

The underlying training philosophy for chasse pilots seemed to be that since these men were to fly alone in single seat aircraft, they would train alone in the aircraft. The chasse pilot had no dual instruction in his training. It worked like this:

The student reported to his first training squadron, received ground instruction in numerous aviation and aircraft related subjects, and was assigned to a flight instructor. The flight instructor prepared the student to operate an aircraft with no wings; obviously the machine would not fly, thereby its name was the Penguin. The goal of this phase of training was to prepare the student to operate the aircraft on the ground, which was no small feat. This wingless aircraft was equipped with a rotary engine and the pilot had a very limited control of engine speed. The cockpit had a throttle and air mixture control that was largely ineffective. In essence, the engine was running either at full tilt or at idle.

The only other engine speed control that the pilot had at his command was a group of "blip" buttons. When pressed, the button would ground the magnetos that would deny an electrical spark to the selected engine cylinders and the cylinders would quit running. Controlling the blip buttons was a critical skill to learn. If one held the blip buttons in too long, the affected cylinders would load up and would not restart once the buttons were released (Woodhouse, 1918, pp. 9-16).

Captain Bishop, the famous Canadian Balloon Buster, provides a vivid illustration of this point. "I. . . spotted my balloon, now on the ground. I dived again, absolutely vertical. At 500 feet, I commenced to fire flaming bullets at it. At 200 feet it burst into flames. .. . Then horror of horrors, my engine would not pick up. I glided over the country and prepared to land my machine and burn it. . . I worked frantically with the throttle and adjustments, and with a roar she picked up and I raced twenty-five feet up...." (Woodhouse, 1918, pp. 9-16).

To make matters more difficult for the fledgling pilot, the characteristic of the rotary engine was that the crankshaft of the engine was fixed while the cylinders and propeller rotated around the crankshaft. This terrific mass moving at high speed induced a turning moment that made controlling the aircraft extremely difficult whether on the ground or in the air.

Additionally, the aircraft was equipped with a tail skid instead of a tail wheel. To turn the aircraft, the student had to give the engine a burst of power that would lift the tail then kick the rudder in the direction of the turn while the tail was up. Turning to the right was relatively easy since the mass of the rotating engine was aiding the turn. Compared with a right turn, turning to the left was a maneuver from hell since the moment produced by the whirling engine mass had to be overcome to accomplish the maneuver.

During this early phase of training, there were many accidents as the pilots were turned loose on an open field to accomplish a variety of ground maneuvers. When the students were able to control the airplane without killing anyone or tearing up the airplane, they were graduated to the next phase of flight.

In the second stage of training, the students trained on aircraft similar to those in the first stage, except, the aircraft had short "clipped" wings. The wings provided enough of a lifting surface for the students to get ten or fifteen feet in the air with a good run into a crisp headwind. Often, the instructor would stand on one of the stubby wings and shout encouragement to his student. The purpose of this phase of training was to enable the student to gain skills in both takeoff and landing. Once the student mastered this stage of training, he was sent to yet another field for continued training.

The third stage of training was conducted in a combat aircraft. The assigned instructor carefully briefed the student on various flight procedures and techniques and peculiarities of the airplane. The student then took off, made one circuit of the field and landed, all within view of the instructor. Next came a series of tasks of ever increasing complexity to include flight maneuvers, navigation, aerobatics, formation flying, airto-air engagement tactics, and ground attack techniques and procedures. Upon completion of this training the pilot was posted to a line unit for duty as a combat chasse pilot. (See also "Tricks and Acrobatics of the Air Fighter. . " Scientific American, September 17, 1918, p. 188.)

\section{The German System}

The Germans used a pilot training system very similar to that of the British. The system was very effective in producing well-trained pilots when it was used properly. However, when times were rough at the front, the Germans would send their skilled instructors to combat, which slowed pilot production dramatically. The time it took to train other instructors cost them dearly in their push to keep up with battlefield attrition.

\section{The American System}

When the U.S. entered the war there were very only sixtyfive army pilots, a skimpy number of training fields, three, and 
very few training aircraft. The training fields were located at Mineola, New York ( Long Island), Essington, Pennsylvania and San Diego, California. The total air arm of the Signal Corps including pilots, mechanics, cooks and clerks amounted to only 1,200 people counting both officers and enlisted. It was clear from the start that the U.S. was going to have to conduct a large part of the training. The facilities in Europe were not capable of handling the numbers of American aviators that needed to be trained.

The U.S. adopted elements of the English Gosport system in that three phases of training were conducted, ground, primary and advanced. For the first phase of training, the ground phase, the Army turned to the Universities: the Universities of California, Illinois, and Texas plus Ohio State University, Massachusetts Institute of Technology, Princeton University, Georgia Institute of Technology, and Cornell University. Each of these universities established School of Military Aeronautics.

While spending eight to twelve weeks at one of the universities, the cadet received instruction in theory and principles of flight, use of the machine gun, operation and care of aircraft engines, assembling and care of aircraft airframes and components, theory and operation of radios (wireless telegraphy), the use of code, principles of aerial tactics, map reading and cross country navigation, principles of photography, meteorology, astronomy, and a collection of military courses including military law, discipline and military customs and courtesies. The cadet was to be an Army officer and soldier, albeit a flying one, and also received a substantial amount of military training in classical areas such as, drills, calisthenics, and behaviors expected of an Army officer.

Once the cadet completed the ground phase of training, he was posted to a flying field where he would receive flight training. In the summer of 1917, there were not enough U.S. flying fields to meet the demand so training fields in Canada were used. Through its various contractors, the Signal Corps was building training facilities at a vigorous rate. By December, fifteen training sites were open for business. These included many facilities that are still open today in some form or another such as Kelly Field and Brooks Field in San Antonio, Texas, Love Field at Dallas, Texas, Wellington Field at Houston, Texas, Scott Field at Belleville, Illinois, Chanute Field at Rantoul, Illinois, Selfridge Field at Mt. Clemens, Michigan, Wright Field at Dayton, Ohio, Langley Field at Hampton, Virginia. Mather Field in Sacramento, California, and Post Field at Ft. Sill, Oklahoma.
The cadet typically spent six to eight weeks at the primary training site where he received training in the American-built JN-4 Jenny. Initially the training was not standardized, but as the lessons of the Gosport system were implemented, standardized training followed. The cadet received about forty to fifty hours of flight training composed of both dual and solo flight training events. The cadet was given a flight exam at the end of training, called the RMA (Reserve Military Aviator test). If successful, the cadet received both his pilot $=\mathrm{s}$ wings and an Army commission as a second lieutenant. From primary training, the graduate was usually sent to some training facility in Europe (England, France or Italy) for advanced training.

Of the 15,000 cadets who entered pilot training, approximately 8,700 were graduated making the "washout rate" about $42 \%$. Another 1,000 or so cadets received their primary training in Europe (500 plus in England and 444 in France). Some of these had experiences that tested their morale and resolve. For example, several hundred cadets were posted to a primary flight training school in Issoudun, France, a facility that was still under construction and was not yet equipped with primary training aircraft. The cadets found themselves doing construction work and other unexpected and menial tasks. Delay after delay forced their start training dates forward and many of them entered training just as their counterparts who were trained in the U.S. were arriving in Europe sporting their wings and commissions. In an effort to correct the inequity, the Army commissioned these "European cadets" at a time corresponding to the time they would have been commissioned had they trained in the U.S.

The advanced flying course in France took from two to three weeks to complete. The pilot received both dual and solo training in five different aircraft. Each aircraft was more difficult to fly, was faster, and the maneuvers were more difficult to accomplish as the aviator moved up the scale. As the pilot trainee progressed from airplane to airplane, the wings on the biplanes got shorter and the engines grew larger. The first aircraft had a wing spread of 28 meters and was equipped with an 80-horsepower engine. The next machine had a wingspan of 23 meters followed by one with 18 meters and a 110-horsepower engine. The fourth and fifth in the series were single seat aircraft; the fourth had a wingspan of 15 meters and the final aircraft had a wingspan of 13 meters with $125 \mathrm{HP}$ engine (Woodhouse, 1918).

After becoming proficient in the fifth aircraft, the pilot practiced the finishing touches as told by Henry 
Woodhouse (1918), a famous aviation expert of the day:

A week of aerobatic flying follows, during which the now full-fledged aviator practices banking at an angle of ninety degrees, "cork screwing" down with the machine descending faster than in a vertical dive; side-slipping, nose-diving and flying in squadron formation.

Then comes the period of transformation, during which the pilots practice the use of machine guns on different types of aeroplanes, shooting at toy balloons, and flying from four to ten hours each day, while waiting to be called to join a squadron at the front (pp, 9-16).

The front was the final examination, the test of combat, giving true meaning to the term "final exam." At the front in 1918 , the life expectancy of a pilot was six weeks. There it did not take long to test the validity of flight training theory.

Today, when we look closely at American pilot education and training either in university programs, the military or elsewhere, we'll find elements of the Gosport system such as, standardized curriculum, checkrides by instructors different from the assigned instructor, progression from the simple to the complex aircraft. To a smaller degree, we also find the brashness of the French chasse system, in that we prepare students to solo and demand that a component of the training is conducted while solo. We also learned from the Germans, particularly from the military point of view in that when things get tough at the front, you don't strip away your quality instructors for combat duty.

Whether one considers a civilian or a military application of flight education, many of the concepts that we practice today were gained through the bitter learning curve of conflict.

Tim Brady holds a $\mathrm{Ph}$.D. in Education in Higher Education Administration from St. Louis University, a Master of Science Degree in Management from Abilene Christian University, and a Bachelor of Science Degree fromTroy State University. He is currently the Dean of the School of Aviation at Embry-Riddle Aeronautical University in Daytona Beach, Florida. He also serves on the Board of Trustees of the Council on Aviation Accreditation and is the Chairman of its Curriculum Committee. He is dual rated as a pilot and navigator and currently holds the Air Transport Pilot (ATP) rating (multi and single engine with commercial privileges). 


\section{BIBLIOGRAPHY}

Note: This is a greater bibliography than was used for this current article, although the references cited in the article are contained herein. The article was an excerpt from the author's contribution to the textbook The American Aviation Experience, soon to be published by Southern Illinois University Press and used here with their permission. This bibliography is provided in this depth for the serious student of World War I.

Arnold, Henry H., AHistory of the Aviation Section (Signal Corps) and Division of Military Aeronautics, April 1917 to October 1918. (unpublished) Washington D.C.: Library of Congress, 1918.

Berry, W. H. Aircraft in War and Commerce. New York: George H. Doran, 1918.

Brachner, W. S., Brigadier-General, Training in Military Aviation, "The Methods of the British Schools," Scientific American Supplement No. 2155, Vol. 83, April 21, 1917, pp. 242-243.

Brett, R. Dallas. History of British Aviation, Surrey, England: Air Research Publications, 1933.

Brown, Carl A. A History of Aviation. Daytona Beach: Embry-Riddle Aeronautical Univ. Press, 1980.

Chapman, Victor E., Victor Chapman's Letters from France. New York: Macmillan Company, 1917.

Cooke, David. The Planes They Flew in World War I, New York: Dodd, Mead, 1969.

Faulkner, G. L., Lieutenant, "Britain's Bid for the Control of the Air, Training the British Airman for Army and Naval

Service," Scientific American 116 (April 28, 1917): 422-423.

Gibbs-Smith, C. H. Flight Through the Ages, New York: Thomas Y. Crowell, 1974.

Hudson, James J. Hostile Skies. Syracuse: Syracuse University Press, 1968.

Jones, Ira. King of the Air Fighters. London: Greenhill Books, 1934.

Knappen, Theodore M. Wings of War, New York: G.P. Putnam, 1923.

McConnell, James R., Flying for France. New York: Doubleday, Page \& Co., 1917.

Mingos, Howard. The Birth of an Industry. New York: W. B. Conkey, 1930.

Mixner, G. W. and Emmons, H. H. U. S. Army Aircraft Production Facts, Washington D. C.: G.P.O., 1919.

Norman, Aaron. The Great Air War. New York: Macmillan, 1968.

Page, Victor W., Lieutenant. "Development of Aviation Engines," Scientific American, 117 (October 6, 1917): 247, 258-259.

Patrick, Mason M. The United States in the Air, Garden City: Doubleday, 1928.

Person, Henry G. A Business Man in Uniform: Raynal Cawthorne Bolling, New York: Duffield, 1923.

Rae, Jophn B., Climb to Greatness: The American Aircraft Industry 1920-1960. Cambridge: MIT Press, 1961.

Report Number 555, "Aircraft Production" Congressional-Record, 56., 65th Congress, 2nd Session, August 22, 1918.

Reynolds, Quentin. They Fought for the Sky. New York: Rinehart, 1957.

Rickenbacker, Eddie V. Captain. Fighting the Flying Circus. Garden City, N.J.: Doubleday, 1965.

Saunders, Hilary St. George, Per Ardua The Rise of British Air Power $=\underline{1911-1939}$, London: Oxford Univ. Press,

1945.

Unwin, 1971.

Setright, L.J.K. The Power to Fly The Development of the Piston Engine in Aviation., London: George Allen \&

Simonds, Frank H. History of the World War (in four volumes). Boston: Houghton Mifflin, 1922.

Simonson, G. R. (ed.). The Histony of the American Aircraft Industry. Cambridge: MIT, 1968.

Smith, Daniel M. American Intervention. 1917: Sentiment, Self-Interest or Ideals? Boston: Houghton Mifflin, 1966.

"Tricks and Acrobatics of the Air Fighter, What the Pilot is Taught at the French Finishing School." Scientific

American, 119 (September 17, 1918) 188.

Walcott, Stuart. Above the French Lines. Princeton: Princeton University, 1918.

Williams, Archibald. Conquering the Air. New York: Thomas Nelson, 1926.

Williams, Bertram W. "Recent Enemy Aircraft." Scientific American 119 (October 5, 1918): 274.

Williams, Bertram W. "The Classification of Military Aeroplanes." Scientific American 119 (October 5, 1918): 248-

251.

Woodhouse, Henry. "Training our Army 'Eagles.'" Everybody's Magazine 38 (January 1918): 9-16.

Wortley, Rothesay S. Letters from a Flying Officer. London: Oxford University Press, 1928. 